\title{
New Evidence for Early Silk in the Indus Civilization
}

\section{Citation}

Good, I. L., J. M. Kenoyer, and R. H. Meadow. 2009. "New Evidence for Early Silk in the Indus Civilization." Archaeometry 51, no. 3: 457-466.

\section{Published Version}

doi:10.1111/j.1475-4754.2008.00454.x

\section{Permanent link}

http://nrs.harvard.edu/urn-3:HUL.InstRepos:14117751

\section{Terms of Use}

This article was downloaded from Harvard University's DASH repository, and is made available under the terms and conditions applicable to Other Posted Material, as set forth at http:// nrs.harvard.edu/urn-3:HUL.InstRepos:dash.current.terms-of-use\#LAA

\section{Share Your Story}

The Harvard community has made this article openly available.

Please share how this access benefits you. Submit a story.

Accessibility 


\section{New Evidence for Early Silk in the Indus Civilization}

Irene L. Good, + J. Mark Kenoyer, and Richard H. Meadow

\section{Summary}

Silk is an important economic fiber, and is generally considered to have been the exclusive cultural heritage of China. Silk weaving is evident from the Shang period, though the earliest evidence for silk textiles in ancient China dates to more than a millennium earlier. New study of fibers from Harappan bronze artifacts reveals surprising early evidence for knowledge of silkworking in South Asia, the earliest evidence in the world for any silk outside China, and roughly contemporaneous with the earliest Chinese evidence for silk. This important new finding brings into question the traditional historical notion of sericulture as being an exclusively Chinese invention.

\section{Background}

The Indus Civilization, c. 2800-1500 BCE, was one of the great river civilizations of the ancient world. Current understanding of this urban culture is that it was generated out of earlier diverse, regional cultures that interacted with each other economically and socially. Thus within a very large area around the Indus river valley (in Sindh, Pakistan), the Indus Civilization extended from the Himalaya and Hindu Kush to the coastal regions of Kutch and Gujarat; westward into Baluchistan and eastward into northwestern India; covering an area larger than that of Mesopotamia or of Egypt. Harappa was the first of the Indus cities to be discovered. For nearly a century excavations have taken place in the eponymous city. The florescence of the Indus culture (2600-1900 BCE) is known as the Mature Harappan.

More than a few enigmas concerning the Indus Civilization still vex archaeologists, not least of which is the lack of substantive evidence for reciprocal exchange of commodities with Mesopotamia, where Indus-produced luxury materials are found in such places as the royal graves at Ur. Yet to date, no Mesopotamian materials have ever been recovered from Indus sites. Recent microscopic analysis of archaeological thread fragments found inside bronze and chlorite beads from two important Indus sites, Harappa and Chanudaro (ca. 2600-2200 BC) have yielded silk fibers. Could this be evidence for sericulture in the Indus civilization that developed independently from that of early China?

Recent work at Harappa has been jointly carried out by a team from the University of Wisconsin at Madison, New York University and Harvard University, under the auspices of Harvard's Harappa Archaeological Research Project (HARP). New study of artifacts recovered from the one of the last seasons of excavation at Harappa (1999) has revealed the presence of silk. The silk is not degummed but contains sericin-coated twinned brins, or filaments, of fibroin. Micromorphological study indicates wild silkmoth species rather than Bombyx mori. To assess the culture-historical significance of these new silk finds we take into account several wild silkmoth species known to South Asia, understanding that the real nature and extent of sericulture in antiquity is at present unknown. It has been assumed that Bombyx mandarina (Moore) was domesticated in China into the wellknown (and only domesticated) insect B. mori (Chang 1986; Kuhn 1982). The earliest

+ Author to whom correspondence should be addressed 
evidence dates to ca. 2700 BCE from Qianshanyang (Zhou 1980). However $B$. mandarina (Moore) is also native to South Asia.

Not only has early evidence for silk been assumed to be Chinese, but the techniques of degumming and reeling are also considered exclusively Chinese silk industry 'secrets'. The process of de-gumming, is where the sericin gum is removed from the silk, by submerging the cocoons into a weak alkaline solution. Reeling silk is a process by which the long silk strands (gummed ot not) are collected onto a bobbin rather than needing to be twisted as short segments into a spun thread. These two important silkworking processes have been thought to be part of a 'package' of Chinese technology known only to China until well into the early centuries $\mathrm{AD}$, although the evidence presented here indicates that wild Antheraea silks were also known and used in the Indus as early as the mid-third millennium BCE, and that reeling was practiced. The implication of evidence for silk reeling is that the silkmoth was stifled, leaving the cocoon intact in order to be unraveled. When wild silk cocoons are collected on the ground, usually after the silkmoth has eaten its way out, the remaining silk fibers must be spun rather than reeled, as they are short.

This new discovery of silk in the Indus Valley pushes back the earliest date of silk outside of China by a millennium. Specific contributions of the present paper include discussion of new silk finds from Harappa and Chanudaro along with SEM imaging of modern wild specimens of Antheraea assamensis and A. mylitta silk.

\section{Methods}

Thread samples were first investigated under a low-power binoular microscope for possible fiber identification. The samples were then examined and imaged under a highpower polarizing microscope using auxillary fiber optics and high depth of field, allowing optimal view of extant fiber surface structures. After this, samples were coated with a 5-angstrom coating of Ag and examined under a LEO A FESEM scanning electron microscope at 15 and $20 \mathrm{kv}$ at Harvard University's Center for Imaging and Mesoscale Structures. Determinations were based on comparative silk specimens, viewed under SEM, collected from cocoons sampled from the Entomology Departments of the British Museum of Natural History and the Philadelphia Academy of Natural Sciences.

\section{Results}

\section{Harappa}

A thread sample was removed from a copper bead excavated at Harappa in 1999 (H 99/8863-2 [168]; lab 99:4488). It is comprised of two fragments: one disintegrated (designated 'A') and the other still retaining some thread structure ('B'). These two samples are of the same thread, and are comprised uniformly of the same type of fiber. Partial mineralization and fiber disintegration hampered a simple and straightforward identification of thread sample H99/8863-2. The thread itself is a slightly ' $\mathrm{S}$ ' twisted (at about $10^{\circ}$ ), two-plied thread with approximately 60-75 ' $Z$ '-spun strands in each ply. 
Scanning electron micrographic survey of various sites on both sample fragments ' $A$ ' and ' $\mathrm{B}$ ' produced a reasonably secure morphological determination of silk, and possible further determination of silk from the A. assamensis species (see table I and figures 1-2).

\begin{tabular}{|c|c|c|c|c|c|c|}
\hline HARP ID\# & Locus & Material & Context & Level & Date (cal) & description \\
\hline $\begin{array}{c}\text { H 99/8863-2 } \\
\text { lab 99:4488 } \\
\text { A }\end{array}$ & $\begin{array}{l}\text { inside } \\
\text { copper } \\
\text { bead }\end{array}$ & $\begin{array}{l}\text { silk } \\
\text { thread } \\
\text { fibers }\end{array}$ & $\begin{array}{l}\text { Trench } \\
11\end{array}$ & IIIB & $2200 \mathrm{BCE}$ & $\begin{array}{l}\text { S plied Z twist } \\
\text { cf. A. assamensis }\end{array}$ \\
\hline $\begin{array}{c}\text { H 99/8863-2 } \\
\text { lab 99:4488 } \\
\text { B }\end{array}$ & $\begin{array}{l}\text { inside } \\
\text { copper } \\
\text { bead }\end{array}$ & $\begin{array}{l}\text { silk } \\
\text { thread } \\
\text { intact } \\
\text { fragment }\end{array}$ & $\begin{array}{l}\text { Trench } \\
11\end{array}$ & IIIB & $2220 \mathrm{BCE}$ & $\begin{array}{l}\text { S plied Z twist } \\
\text { cf. A. assamensis }\end{array}$ \\
\hline $\begin{array}{l}\text { H2000/2242- } \\
1 \text { lab 2000- } \\
1955\end{array}$ & $\begin{array}{l}\text { inside } \\
\text { copper wire } \\
\text { ornament }\end{array}$ & $\begin{array}{l}\text { silk } \\
\text { thread }\end{array}$ & $\begin{array}{l}\text { Trench } \\
54\end{array}$ & IIIC & $2450 \mathrm{BCE}$ & $\begin{array}{l}\mathrm{Z} \text { twist } \\
\text { single ply } \\
\text { cf. } A \text {. mylitta }\end{array}$ \\
\hline
\end{tabular}

Table I. Fiber samples from Harappa identified as silk

A

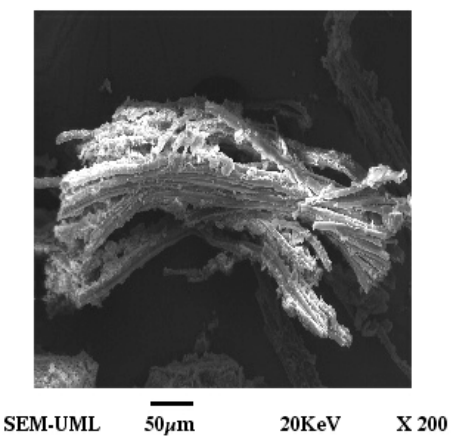

B

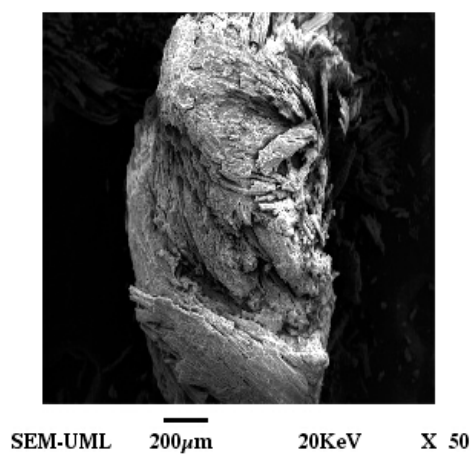

A

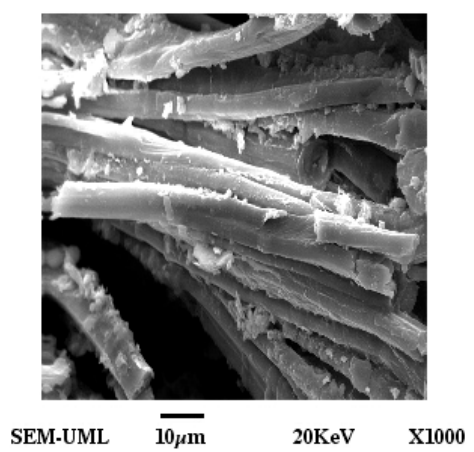

B

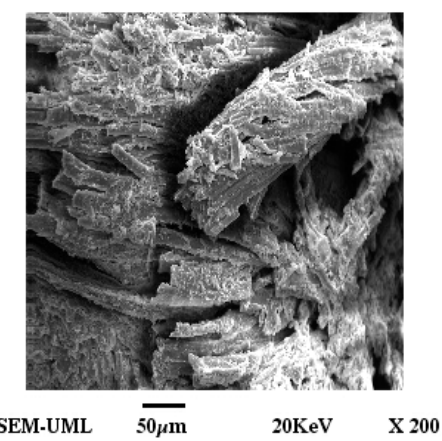

Figure 1. Scanning electron micrographs of archaeological thread sample, views of parts 'A' and 'B' from Harappa (H 99/8863-2). Photomicrograph by I. Good and B. Chang. 


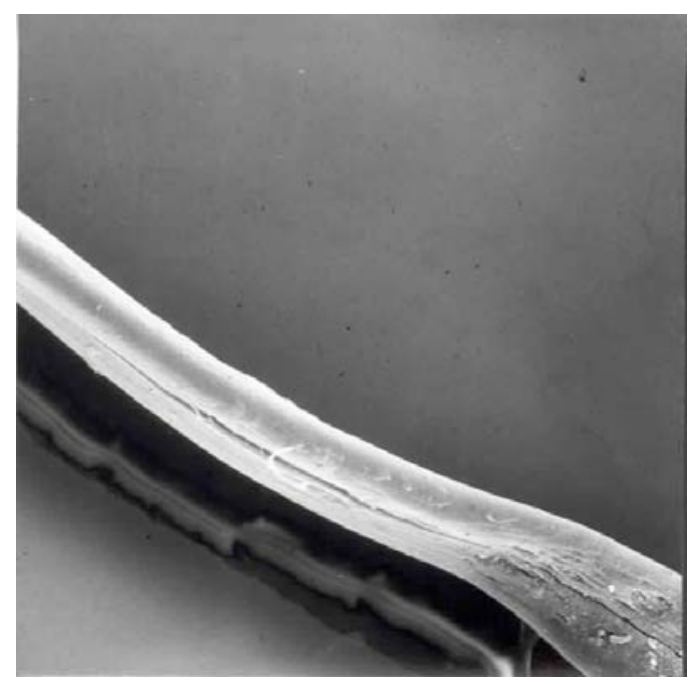

Figure 2. Modern specimen of A. assamensis silk. Photomicrograph by I. Good and J. Hather.

A second thread sample from Harappa (H2000/2242-1 lab 2000-1955), was recovered in the 2000 field season. This sample also came from within a copper bead, and is also of a wild Antheraea silk, but appears to be from a different species, A. Mylitta, as it has a distinctive striated fiber (figures 3-5). The particular shape of each type of silk is due to the unique shape of the silkworm's orifice when ejecting fibroin during cocooning. In this case, striations are characteristic of $A$. Mylitta silk. These two species are indigenous to South Asia. A. assamensis is found in the high altitudes of the northeastern subcontinent, and $A$. mylitta is found along the tropical west coastal region.

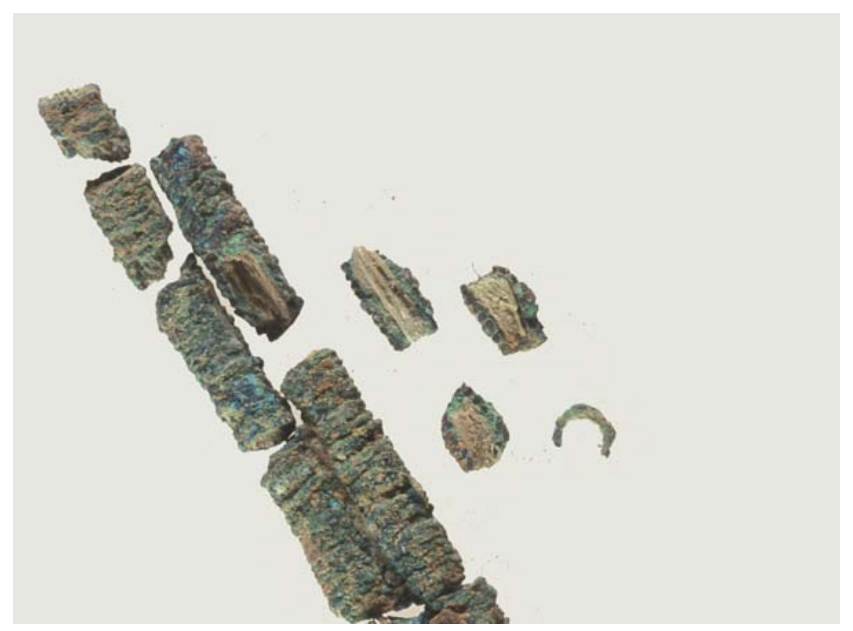

Figure 3. Copper wire beads from Harappa ca. 2200 BCE revealing intact thread. Photograph by J.M. Kenoyer. 


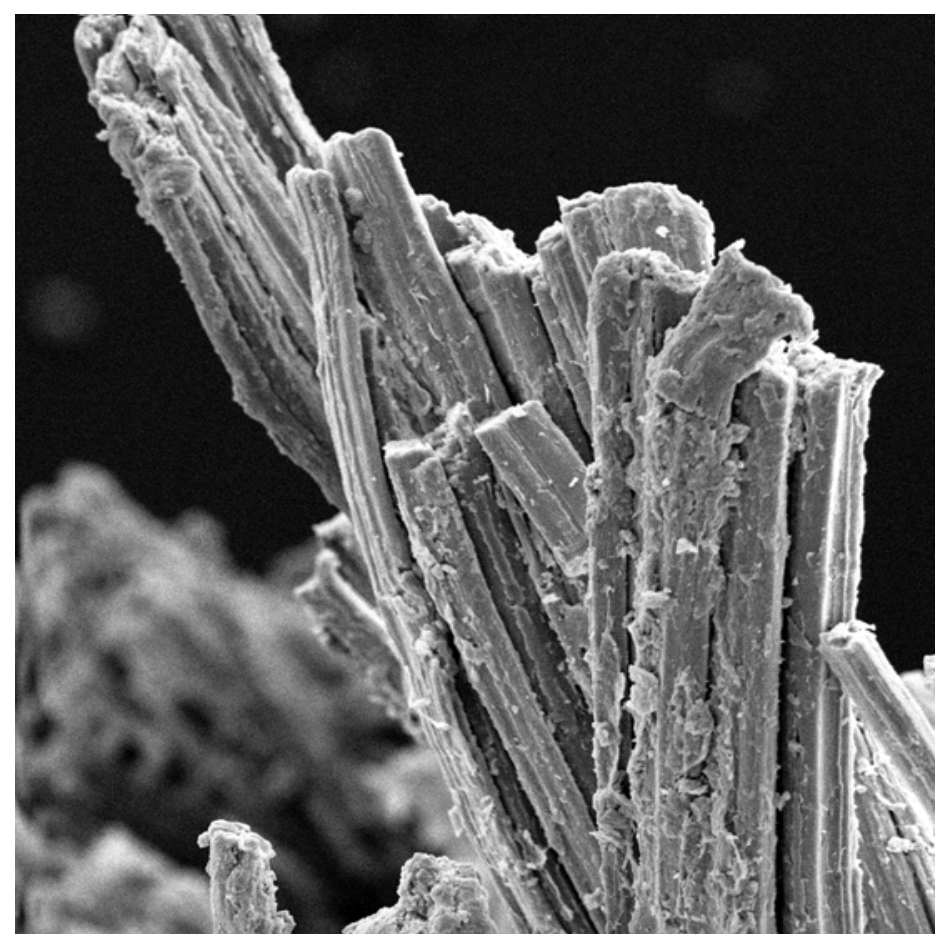

Figure 4. Harappa 2242-1. Image showing ends and brins with longitudinal striations characteristic of $A$. mylitta. Photomicrograph by J.M. Kenoyer.

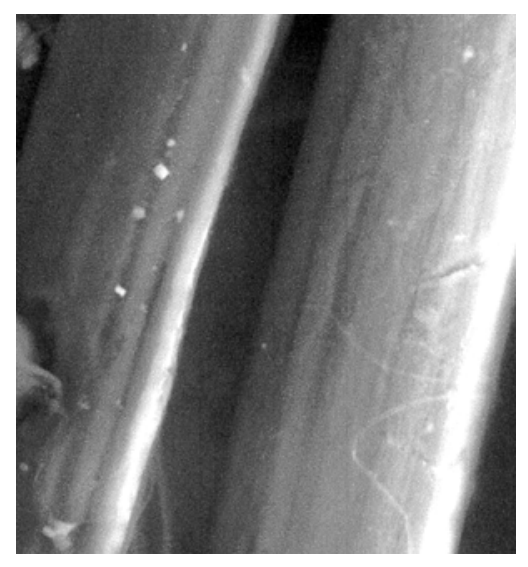

Figure 5. Modern specimen of Antheraea mylitta showing distinctive longitudinal striations in fibroin brins. Photomicrograph by I. Good and M. Derrick.

\section{Chanudaro}

Chanudaro is another important early urban site of the Indus Civilization which thrived during the third millennium BCE in the Indus Valley. It was excavated in the 1930s by Ernest Mackay through the sponsorship of the Boston Museum of Fine Arts. Recent survey of excavated small finds (principally bronze artifacts such as razors and bowls) currently in the Boston MFA collections revealed several objects with either textile 'pesudomorph' or actual extant textile adhering to surfaces of objects. One object, a heat- 
fused cluster of microbeads from a bronze bowl, had been published in Mackay's catalogue (\#2391B). The microbeads contained therein were noted to include intact thread remains. (see figures 6 and 7).

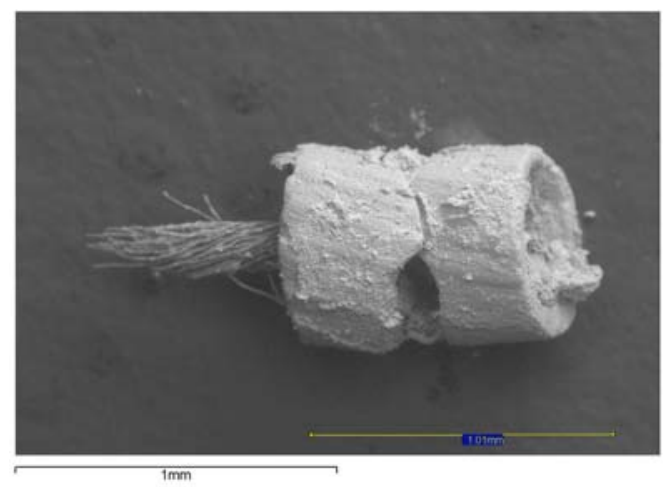

Figure 6. Microbead from Chanudaro showing slightly ' $\mathrm{S}$ ' twisted single ply thread. Photomicrograph by I. Good and R. Newman.

Microbead and thread samples from this object from Chanudaro were removed and analyzed. The thread consists of a single ply of approximately 40-50 strands, with a slight 'S' twist (approximately 12-15 degrees). Fibers from the thread were studied under SEM at $20 \mathrm{kv}$ without sputtercoating. They appear partially gummed and partially twinned, characteristic of a reeled (but not degummed) silk. The fibers are from A. assamensis.

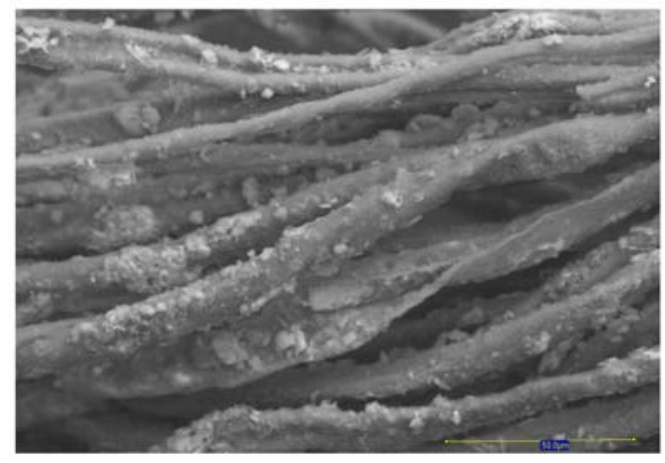

Figure 7. Fibers from microbead. Photomicrograph by I. Good and R. Newman. 


\section{Discussion}

The formal exportation of silk from China took place around 119-115 BCE, during the reign of Han Emperor Wu-ti who sought the fabulous blood-sweating 'celestial horses' of Ferghana (in modern day Uzbekistan), yet archaeologists have puzzled over the early presence of silk in a late prehistoric Celtic site in Germany ca. 700 BCE, as well as silk finds from several other sites in Europe, the Mediterranean, Egypt and Central Asia (see, for example, Lubec et. al 1993; Braun 1987; Wild 1984; Askarov 1973; Hundt 1971; Richter 1929). For decades, archaeologists have cited these findings as evidence of early contact between China and the West (for full discussion see Good 1995; see also Good forthcoming). What has not been adequately considered in the literature, however, is the possibility that a non-Chinese (and de facto wild) species of silkworm which produced workable silk was known and used in antiquity, and that the rare instances of silk that have been discovered far outside of China before Wu-ti's trade relationship with the West began may have in fact been produced indigenously. The evidence presented here now suggests that early sericulture existed in South Asia, and was roughly contemporaneous with the earliest known silk use in China.

\section{Conclusions}

This research offers new insight on the extent and antiquity of sericulture. Specifically, these finds suggest the use of wild indigenous silkmoth species in South Asia during the mid-third millennium BCE. Careful morphological study of highly degraded fibers through images derived from scanning electron microscopy allows subtle but distinct and diagnostic features of fiber surface and fiber shaft morphology to aid in species identification. At least two if not three species of silk were utilized in the Indus in the mid-third millennium BCE. There are two distinct thread forms in the samples from Harappa, and they appear to be from two different species of silkmoth (Antheraea sp.), based on SEM image analysis. The silk from Chanudaro is of another (yet unidentified) species, possibly an Eri silk (Philosamia spp.). It appears to be reeled.

\section{References}

Askarov, A, 1973. Sapallitepe. Tashkent. (unpublished translation by H. Michael).

Braun, T, 1987. The Earliest Silk in Europe. unpublished ms. Merton College, Oxford.

Chang, KC, 1986. The Archaeology of Ancient China. Yale University Press, New Haven. fourth edition.

Freina, J and T Witt, 1987. Die Bombyces und Sphinges der Westpalaerktis Edition Forschung \& Wissenschaft Verlag, München.

Good, IL, forthcoming. When East Met West: Interpretive Problems in Assessing EastWest Contact and Exchange in Antiquity. Vth ICAANE Congress, Madrid. Edited by 
Allison Betts and Fiona Kidd. Ancient Near Eastern Monograph Series, Peeters, Louvain.

2001. Archaeological Textiles: a Review of Current Research. Annual Review of Anthropology 30:209-226.

1995. On the Question of Silk in Pre-Han Eurasia Antiquity 69:945-958.

Good. IL and EJ Kim, 1994. Final Research Report on the Silk Project. (research supported by the University of Pennsylvania Research Foundation.) unpublished ms.

Gulati, AN, 1961. A Note on the Early History of Silk in India. pp. 53-59 in: Technical Reports on Archaeological Remains III. J. Clutton Brock, Vishnu-Mittre and A. N. Gulati, eds. Poona.

Hundt, H-J, 1971. On Prehistoric Textile Finds Jahrbuch der Römisch Germanisches ZentralMuseum vol. 16, Mainz.

Jakes, K, 2000. Microanalytical Methods for the Study of Prehistoric Textile Fibers. pp. 51-59 in P. Drooker and L. Webster, Beyond Cloth and Cordage. Archaeological Textile Research in the Americas. University of Utah Press, Salt Lake City.

Kenoyer, JM, 1998. Ancient Cities of the Indus Valley Civilization. Oxford University Press, Oxford.

Kuhn, D, 1982. The Silk Workshops of the Shang Dynasty 16th-11th Century BC pp. 367-408 in: Explorations in the History of Science and Technology in China. $\mathrm{Hu}$ Daojing, exec. ed. Shanghai Classics Publishing House, Shanghai.

Lubec, G, J Holaubek, C Feldl, B Lubec and E Strouhal, 1993. "Use of Silk in Ancient Egypt". Nature 362:25.1.

Lucas, F, and Rudall, KM (1968). Extracellular fibrous Proteins: The Silks. ch. VII (pp.475-558) in: Comprehensive Biochemistry. (Florkin, M. and Stotz, E. H., ed.) vol. 26B, Elsevier, Amsterdam.

Nunome, J, 1992. The Archaeology of Fiber Before Your Eyes: a compilation of photographs of fiber artifacts. Senshoku to Seikatsusha. Kyoto.

Peigler, R, 1993. Wild Silk Moths of the World. American Entomologist 39(3):151-161.

Richter, GM. 1929. Silk in Greece. American Journal of Archaeology 33:27-33.

Vanden Berghe, I and J Wouters, 2005. Identification and Condition Evaluation of Deteriorated Protein Fibres at the Sub-Microgram Level by Calibrated Amino Acid Analysis. 2004 Textile Conservation Centre Conference Proceedings (preprint). Southampton. 
Wild, JP, 1984. Some Early Silk Finds in Northwest Europe. The Textile Museum Journal 23:17-23.

Wuxing Qianshanyang yiji diyerchi fajue baogao. Kaogu Xuebao 2:73-92. (1960).

Zhou, K. 1980. Qianshanyang canjuanpian chutu de qishi. Wenwu 1:74-77.

\section{Acknowledgements}

The authors wish to thank David Lange and Richard Schalek, Harvard University Center for Nanoscale Systems (Center for Imaging and Mesoscale Structures); Bongwoo Chang, Changmo Sung, Dept. of Engineering, University of Massachusetts, Lowell; David Goodyear, Dept. of Lepidoptera, British Museum of Natural History; Jonathan Hather and Gordon Hilman, Institute of Archaeology, University of London; Richard Newman and Michele Derrick, Museum of Fine Arts, Boston; Don Azuma, Dept. of Lepidoptera, Academy of Natural Sciences, Philadelphia; William Telfer and Eugene J. Kim, formerly of the Department of Biology, University of Pennsylvania; Marian Goldsmith, Dept. of Biology, University of Rhode Island, Michael Cook and Steve Farmer. This research was funded through generous support from the Harappan Archaeological Research Project (HARP) at Harvard University and the American Philosophical Society.

\section{Author Contributions}

R. H. Meadow and J.M. Kenoyer excavated the Harappa materials. R. H. Meadow and J.M. Kenoyer recovered samples and brought them to I.L. Good. I.L. Good analysed the thread samples, including the one from Chanudaro. I.L. Good wrote the article and produced the images and figures, except figures 3 and 4.

\section{Author Information}

Reprints and permissions information is available at:

npg.nature.com/reprintsandpermissions

Correspondence and requests for materials should be addressed to igood@fas.harvard.edu 